\title{
Facing the problem of evil
}

Visual, verbal and mental images of (in)humanity

\author{
Claudia Welz
}

AвSTRACT - This article explores imagination as a means of ethical re-orientation in the aftermath of atrocity. The discussion of the problem of evil is based on Hannah Arendt's critique of Kant and her notion of 'rootless' rather than 'radical' evil. On this basis, the orienting potential of visual images is investigated with regard to images of violence in the media on the one hand, and, on the other, with regard to Michelangelo's Creation of Adam. Then the role of verbal and mental images of humanity or inhumanity is discussed with reference to the Holocaust survivor Jorge Semprun's testimony in his book Literature or Life. Finally, the biblical motif of the human being created in the image of an invisible God, the imago Dei, comes into view as an exemplary image of humanity that appears in a framework of interpretation where the invisible is mediated with the help of verbal, visual and/or mental images.

\section{Radical vs. rootless evil: from Kant to Arendt}

In Die Religion innerhalb der Grenzen der bloßen Vernunft (Religion within the Boundaries of Mere Reason, I793), Part One, Immanuel Kant famously outlines what he calls 'radical evil in human nature', understood as the indwelling (Einwohnung) of an evil principle alongside the good (I 990: I7-58; I 998: 45-73). According to Kant, the good is identical with the good will of a person, while the propensity to evil in human nature is the frailty in not choosing the good. The latter is also described as the impurity, depravity or perversity of the human heart (cf. Kant I 998: 52-4). Kant here inherits the Lutheran tradition of sin corrupting human-

1 This is the revised version of a lecture given at the workshop and $\mathrm{PhD}$ course 'The Problem of Evil and Images of (In)Humanity' at the University of Copenhagen on 7 October 20I6. I am grateful for extremely helpful comments by two anonymous reviewers. kind; yet, in contrast to the pessimistic assumption of a servum arbitrium that is not capable of anything good when human beings act on their own terms, Kant presupposes that we have the freedom to choose the good. In his view, the two competing principles of good and evil in human nature become enacted via our choices. Thus, evil is not interpreted as a metaphysical problem of privatio boni, a lack of the good, but rather as an ethical issue, as something for which someone is responsible. Evil, then, is not radical in the sense that it is inescapably rooted in human nature, having its radix or root in our heart. Instead, it can only be ascribed to a person who has in actual fact chosen that which is not good.

Kant writes explicitly that the 'propensity to evil in human nature' can be thought of as 'brought by the human being upon himself' (Kant I 998: $52 \mathrm{f}$., italics in the original). As Andrew Benjamin (2016: 105) has pointed out, the problem of evil is in this setting framed as 'the presence of evil' - understood both as its 'actuality' and its 'possibility', since evil neither can be 
mere contingency nor a result of evil nature; instead, Kant moves 'from an originating arché that is static to the presence of an origin as an already present potentiality'. This potentiality indicates human freedom of choice. Insofar as one can put self-love above concern for the general good as the maxim of one's will, one is evil in Kant's eyes, and this implies that evil, for him, 'is not a matter of wicked intentions, but of misordered priorities' (Geddes 20I 3: 222).

In her New York lecture course 'Some Questions of Moral Philosophy' (I965-6), Hannah Arendt comments on Kant by underlining that he regarded moral knowledge, the knowledge of right and wrong, as a matter of course, not moral conduct:

Because inclinations and temptation are rooted in human nature, though not in human reason, Kant called the fact that man is tempted to do wrong by following his inclinations 'radical evil.' Neither he nor any other moral philosopher actually believed that man could will evil for its own sake; all transgressions are explained by Kant as exceptions that a man is tempted to make from a law which he otherwise recognizes as being valid ... No one wants to be wicked, and those who nevertheless act wickedly fall into an absurdum morale - into moral absurdity. $\mathrm{He}$ who does this is actually in contradiction with himself, his own reason. (Arendt 2003: 62; see Bernstein 2002 on Arendt and Kant)

Given that knowing the good does not automatically lead to doing the good, although no-one can regard evil as a goal in itself, the question is: what hinders human beings in willing and realizing the good? Arendt refers to inclinations that can tempt us to will what is wrong and to act wickedly; yet in this case, self-contradiction is ensuing from doing the opposite of what reason prescribes us to do. As it is not just irrational, but also painful to contradict oneself in this way, everyone is interested in avoiding dissonance with oneself: 'it is better to be at odds with the whole world than, being one, to be at odds with myself' (Arendt 2003: 100). Thus, owing to the risk of selfcontradiction or even self-division, there is a strong motivation to resist the temptation to do evil.

How, then, is it possible at all that human beings commit crimes against humanity, the utter culmination of evil? Let us listen to the statements of a contemporary war criminal. The German weekly Die Zeit printed a thoughtprovoking interview with Radovan Karadžić, who in March 2016 was sentenced to 40 years' imprisonment by the International Criminal Court in The Hague for crimes against humanity, war crimes and genocide. During the massacre of Srebrenica, about 8000 Muslims were killed, and the Serbian siege of Sarajevo ended with Serbs shooting starving civilians. Here is an excerpt from the interview:

Die Zeit: Was macht für Sie einen bösen Menschen aus?

Karadžić: Einen bösen Menschen gibt es nicht. Es gibt Menschen, die dermaßen unglückselig und so unglücklich sind, dass sie ihren Kompass verloren haben und sich für schlechte Elemente des menschlichen Wesens entscheiden. Sie haben Denk- und Verhaltensweisen übernommen, die schädlich sind, zunächst einmal für die Personen selbst und dann auch für ihr Umfeld. Keine glückliche Person kann böse sein....

Radovan Karadżić ist unfäbig oder nicht willens, einen Anflug von Reue zu zeigen. Vielleicht empfindet er sie nicht einmal. Im Gefängnis hat er sich seine eigene Gedankenwelt geschaffen, angefüllt mit Selbstbetrug und Verschwörungstheorien, die abgeschlossene Welt eines Unbelehrbaren....

Die Zeit: Wie soll die Welt Sie in Erinnerung behalten? 
Karadžić: Ich weiß, dass die serbische Welt mich als einen aufopfernden und verantwortungsbewussten Staatsdiener in Erinnerung behalten wird. (Willeke 2016: I2, italics in the original)

To sum up: According to Karadžić, there are no evil human beings in this world, but only unhappy people who have lost their moral compass and therefore have chosen bad elements of human nature: ways of thinking and behaving that are harmful for themselves and their surroundings. The thought that a happy person cannot be evil excuses all evil-doers as poor devils who have no luck and get no joy. Revealingly, Karadžić shows no remorse whatsoever. When asked how the world will remember him, he replies that he knows that the Serbian world will treasure his memory as a self-sacrificing and responsible public servant.

Arendt, by contrast, does not accept unhappiness as an excuse for immorality. She ventures the following assumption regarding how a human being can come so far as to commit crimes against humanity that deny others' dignity:

\section{Philosophy (and also great literature ...)} knows the villain only as somebody who is in despair and whose despair sheds a certain nobility about him. I am not going to deny that this type of evildoer exists, but I am certain that the greatest evils we know of are not due to him who has to face himself again and whose curse is that he cannot forget. The greatest evildoers are those who don't remember because they have never given thought to the matter, and, without remembrance, nothing can hold them back. For human beings, thinking of past matters means moving in the dimension of depth, striking roots and thus stabilizing themselves, so as not to be swept away by whatever may occur - the Zeitgeist or History or simple temptation. The greatest evil is not radical, it has no roots, and because it has no roots it has no limitations, it can go to unthinkable extremes and sweep over the whole world. (Arendt 2003: 94f.)

While the monologues of the scoundrels in world literature from Shakespeare to Dostoevsky testify to the fact that they experienced the depth of despair, the Nazi criminals in the twentieth century were apparently too superficial and shallow, too forgetful and thoughtless to reflect upon what they had done and despair about it. Pondering the past means being rooted in history and contemplating the consequences of one's deeds. Considering the evil that led to the Shoah, Arendt discards Kant's notion of radical evil - both in regard to its being grounded in human nature and its historicity. The planning of industrialised genocide required an extraordinary measure of selfevasion and the deliberate loss of memory. Since it was rootless, this evil was also limitless. It could spread because it was not stopped by any scruples. There was no second thought, no regret, no self-criticism on the side of those who were deemed responsible for the crimes.

The connection between thinking and remembering as 'the human way of striking roots, of taking one's place in the world' (Arendt 2003: IOO) has a flipside: where these 'self-grown roots' (ibid. Iо I) are absent, one no longer sets oneself limits: 'If I refuse to remember, I am actually ready to do anything' (ibid. 94). Irresponsibility, then, is due to a peculiar kind of self-forgetfulness: one ignores the link between one's doing and one's being, between personal agency and personal identity. Thus 'the safest way for the criminal never to be detected and to escape punishment is to forget what he did, and not to think about it any more' (ibid.), whereas the one who repents returns to his deeds in thought. Similarly, in Beyond Good and Evil (1886), Friedrich Nietzsche formulates a blessing of the forgetful by imitating and yet reversing 
Jesus's Sermon on the Mount: 'Blessed are the forgetful, for they shall also "be done with" their blunders' (2008: no. 217). Note that this is not an innocent or distrait forgetfulness, but rather one that is tied to self-deception. It is not a coincidence that Arendt (2003: I 24) also quotes the following aphorism by Nietzsche: 'My memory tells me: I did this. My pride replies: I could not have done it. Pride is unrelenting. Finally my memory gives in' (Nietzsche 2008: no. 68). Here repression is part and parcel of the process in which unwelcome self-knowledge is rejected.

Having witnessed the Eichmann trial in Jerusalem in r 96r, Arendt was stunned by the fact that this man - one of the key perpetrators of the Holocaust - did not feel he was caught in any ethical dilemma. Eichmann claimed to have a clear conscience. Her explanation is that his conscience spoke "with the voice of respectable society around him' (Arendt 2006: I26). Without further ado, Eichmann conformed to his social environment, legal authorities and Hitler's words. He understood himself as a law-abiding citizen. In Eichmann's case, it was impossible 'to trace the uncontestable evil of his deeds to any deeper level of roots or motives. The deeds were monstrous, but the doer... was quite ordinary, commonplace, and neither demonic nor monstrous', she explained in The Life of the Mind (Arendt I 978: 4). Arendt expected to meet a monster, but instead 'she found an efficient bureaucrat who routinely sent thousands to their deaths and considered it a day's work' (Geddes 2009: I 23). Arendt termed this widespread everydayness and routinisation of evil-doing the 'banality' of evil (cf. Benhabib I990: I85). 'The trouble with Eichmann was precisely that so many were like him, and that the many were neither perverted nor sadistic', but 'terribly and terrifyingly normal' (Arendt 2006: 287).

This normality was so terrifying for Arendt because it implies that many people can commit crimes without knowing or feeling that they are doing wrong. In the courtroom, Arendt became aware of Eichmann's incapability 'of uttering a single sentence that was not a cliché' (Arendt 2006: 48) and his incapability of changing perspectives by putting himself in another's place: 'The longer one listened to him, the more obvious it became that his inability to speak was closely connected with an inability to think, namely, to think from the standpoint of somebody else' (ibid. 49). Robert Eaglestone (2017: 34) calls attention to the fact that, for Arendt, real communication with others and oneself opens up the reality of the world; conversely, the language of Nazism, of cliché, slogans, stock phrases and evasion, 'is the vector through which ideology destroys or recasts experience and prevents thought'. Eichmann's inability to think entails the 'lack of a dialogic interrogation of a position' (ibid. 35), in particular the lack of self-critical thinking.

Moreover, in claiming only to be a small $\operatorname{cog}$ in the machine of a regime, one shuffles off one's own responsibility and renounces one's personality, thus becoming an evasive 'nobody' (cf. Eaglestone 2017: 65, 67). If one refuses to take upon oneself the responsibility for what one does and for who one becomes through acting like this, one voluntarily places down one's personal qualities, 'as if nobody were left to be either punished or forgiven' - which is, in Arendt's view, the problem with Nazi criminals who 'protested time and again that they had never done anything out of their own initiative ... and that they only obeyed orders. To put it another way: the greatest evil perpetrated is the evil committed by nobodies, that is, by human beings who refuse to be persons' (Arendt 2003: II I). The impersonality of evil implicates another problem: indifference.

People who look away do not stop the crime but join in it: through Weggucken and Mitmachen, one tolerates evil, to say the least, or even causes it (Augstein 2010: I79). This is illustrated by the open letter that Shmuel Zygelboym, the 
representative of the Jewish people of Poland, sent via the New York Times on 4 June I943. The letter begins as follows: 'I take the liberty of addressing to you my last words and through you the Polish government and people of the Allied States and the conscience of the world' (Zygelboym I995: 683). He informed the world about the failed uprising in the Warsaw Ghetto and the deportation and extermination of Jewish people, and he protested against the 'inactivity with which the world is looking on' and permitting the crime to continue, thereby becoming 'accomplices of criminals' when passively observing the 'murder of defenseless millions and the maltreatment of children and women' (ibid.). Today one could say something similar about the tragedy in Syria. What have we learned from history, if anything? And how, if at all, can we guard ourselves against repetitive variations of historical catastrophes?

\section{Thinking as a cure for the 'banality' of evil? A critical appraisal of Arendt's approach}

Given that evil-doing cannot always be traced back to a wicked heart, but often to mere thoughtlessness, a possible cure for the 'banality' of evil would be Nachdenken, thinking about one's deeds, relationships and events happening. Correspondingly, in The Life of the Mind, Arendt (1978: I3) states (I) that 'absence of thought is not stupidity; it can be found in highly intelligent people'; and (2) that 'a wicked heart is not its cause; it is probably the other way round, that wickedness may be caused by absence of thought'. The latter is said in explicit opposition to a phrase of Kant's.

As Arne Johan Vetlesen rightly remarks, 'Arendt, the thinker, never obtained the thought that thinking ... could lead to evil' (200r: 9). Franziska Augstein (2010: 184f.), too, criticizes Arendt's naivety in relying on the formal procedures of a lawsuit, while losing sight of the truism that any accused perpetrator lies as well and as much as he can. Arendt did not know the transcriptions of Eichmann's conversations with SS-officer Willem Sassen, which prove that his antisemitic attitude guided his actions with the aim of killing as many Jews as possible. Eichmann insisted that he was not a normal recipient of orders; otherwise he would in his own eyes - have been stupid. Rather, he saw himself as an 'idealist' who was thinking for himself (Augstein 2010: I84f., with reference to Wojak 200 I: 63, 195, 200). By contrast, Arendt was duped into believing that there was no sign in Eichmann 'of firm ideological convictions or of specific evil motives' (1978: 4). While she did not assume that thinking could produce the good deed as its result, she raised the question of whether our faculty for telling right from wrong might be connected with our faculty of thought: 'Could the activity of thinking as such, the habit of examining whatever happens to come to pass or to attract attention ... be among the conditions that make men abstain from evil-doing or even actually "condition" them against it?' (ibid. 5) In her view, the word 'con-science' points in this direction insofar as it means 'to know with and by myself' and thus conveys knowledge 'that is actualized in every thinking process' (ibid.).

On the one hand, Arendt mistrusted Eichmann's 'good conscience' because as a rule, a 'good conscience' is enjoyed 'only by really bad people', while only 'good people' are 'capable of having a bad conscience' (Arendt I 978: 5). On the other hand, Arendt did not discover how much Eichmann was entangled in Nazi ideology - not only as a victim of propaganda, a poor party hack, but also as an active abuser of language who wanted to manipulate reality and as a moral offender who ascribed to himself the responsibility for what he did. I agree with Hans-Jørgen Schanz (2007: 97) that Arendt's theory of totalitarianism is too narrowly considered insofar as a totalitarian system would not work without some key persons such as 
Hitler, Himmler or Stalin, who cannot be said to be 'thoughtless' in the sense that this word has acquired for Arendt. These key persons were not just anonymous functionaries, but enormously powerful, visible and active leaders who knew exactly what they wanted. Arendt, who at all costs wished to avoid demonising the Eichmann type of evil, achieved an effect that was contrary to her own intentions: the 'banality' of evil was by many people misinterpreted as its alleged harmlessness (cf. ibid. 84).

In fact, it was not she, but Karl Jaspers who brought up this term in a letter to Arendt, dated I9 October 1946, where he voiced a certain disagreement about the question of guilt:

You say that what the Nazis did cannot be comprehended as 'crime' - I'm not altogether comfortable with your view, because a guilt that goes beyond all criminal guilt inevitably takes on a streak of 'greatness' - of satanic greatness - which is, for me, as inappropriate for the Nazis as all the talk about the 'demonic' element in Hitler and so forth. It seems to me that we have to see these things in their total banality, in their prosaic triviality, because that's what truly characterizes them. Bacteria can cause epidemics that wipe out nations, but they remain merely bacteria.... There is no idea and no essence here. (Jaspers I 992: 62, letter no. 46)

Interestingly, Arendt not only took up the term of the 'banality' of evil, but also its description with the help of biological metaphors. Many years later, in a letter to Gershom Scholem from 24 July r 963, Arendt admitted that she changed her mind and no longer, like Kant, spoke of 'radical evil':

It is indeed my opinion now that evil is never 'radical', that it is only extreme, and that it possesses neither depth nor any demonic dimension. It can overgrow and lay waste the whole world precisely because it spreads like a fungus on the surface. It is 'thought-defying', as I said, because thought tries to reach some depth, to go to the roots, and the moment it concerns itself with evil, it is frustrated because there is nothing. That is its 'banality'. Only the good has depth and can be radical.

(Arendt 2007: 47I)

The idea of rootless evil that spreads like rapidly reproducing micro-organisms prevails also in 'Some Questions of Moral Philosophy', where Arendt writes that 'The greatest evil is not radical, it has no roots' but 'can go to unthinkable extremes and sweep over the whole world' (Arendt 2003: 95).

According to Susan Neiman (2002: 301), Arendt's use of naturalist, non-intentional vocabulary for evil that is compared to a fungus and claimed to be banal was Arendt's most significant break with Kant's work. While great temptations can easily be recognised and resisted, contemporary dangers begin with trivial and insidious steps. 'Calling evil banal is a piece of moral rhetoric, a way of defusing the power that makes forbidden fruit attractive' (ibid. 302). Instead of aestheticising evil, thus turning it into an object of fascination, Arendt took an ironic tone toward Eichmann, which created 'distance in place of desire' and limited its appeal (ibid.). To deny that supernatural forces, divine or demonic, are required to account for evil, makes evil comprehensible - at least to some extent; yet, I doubt that Arendt wanted to offer 'a theodicy', as Neiman has it, which would imply that the sources of evil are 'fully within our grasp' (ibid. 303). After all, Arendt does not offer a rational defence of God in the face of evil, nor does she design an 'anthropodicy' or 'cosmodicy' that would justify the righteousness (dikê) of the human being (ánthropos) or the world (kósmos); and simple efforts to continue to believe in humanity or the world despite evil do not deserve the nomenclature 'theodicies'. 
Furthermore, the shallowness of rootless evil that devastates reality by laying waste its surface is by no means a consolation in the sense that the world would still be intact at depth; rather, it is infected everywhere.

In my view, Arendt's metaphors visualise the vastness of an evil that cannot be controlled by the single individual any more. In order to comprehend and control it, a change of the whole system would be required: the transformation of the mindset of a whole nation. Also, we have to take seriously the point where Arendt's vocabulary falls short and cannot meaningfully be applied to human beings: unlike the thoughtlessness of bacteria or a fungus, human thoughtlessness is willed. While no-one intentionally deceives him- or herself, everyone is obliged by his or her self-knowledge; verbose self-defences such as, for instance, the claim that one has only internalised others' norms, are voluntary and show, paradoxically, that one already has become responsible for the appropriation of these norms (see Welz 20r 8: 247).

We have to keep in mind that Arendt's critique of thoughtlessness addresses, first of all, thinking in the sense of 'wondering' and 'pondering'; this differs from cognitive activities in which we fully expect an answer to the problems we are dealing with, for instance when calculating or strategising (see Pack 20I7: I53f.). Eichmann's rationality was 'the restricted one of instrumental reason' suited to practical-technical tasks such as organising the most efficient means to attain a given end, instead of questioning that end; yet, Arendt might also have inquired into the lack of empathy rather than the lack of thinking (Vetlesen 200I: 9).

The fatal self-understanding of Eichmann and Karadžić, which is characterised by deficient insight into the weight of the crimes each of them committed, brings us directly to the next question: what images of (in)humanity can yield navigational tools and norms of orientation?

\section{The role of visual images of inhumanity}

In exploring the power of visual images, let us first pick out counter-images through which we can orient ourselves only via negativa - through turning away from them. Images that portray inhumanity do not function as a model. The media are filled with images of dread: images of terror attacks, shooting rampages and decapitations.

In an article with the programmatic title 'Ansage: Ich will das nicht mehr sehen', Felix Dachsel (2016: 56) asks: 'Why am I watching this?' - 'What does a human being, who films injured persons instead of helping them, think? And what do I feel when I look at this?' He argues that the hope of taming the horror connects us, as if a community of onlookers could prevent another disaster. Since the idea of evil is traditionally tied to darkness, we believe we can chase away the horrendous by being vigilant. Yet terrorists attack us exactly because we circulate the documents that testify to their misdeeds. For Dachsel, terrorism is an act of exhibitionism. While he thought he could control the images he saw, they have taken control of him in his nightmares. The images of the injured impose themselves. Horror sometimes impedes understanding. Maybe, Dachsel deliberates, we should rediscover an old feeling: shame. In times of relentless immediacy, shame could bestow us with sensibility for the question of when we are allowed to look closely and when we rather should avert our eyes. After all, we are ashamed of what human beings can do to each other. Dachsel concludes that looking away, too, can be an expression of compassion (cf. ibid.). ${ }^{2}$

2 My translation and summarising paraphrase. Here is the German original (Dachsel 2016: 56): 'Diese Bilder. Ich hatte schon viele solcher Bilder gesehen, meistens saß ich auf meinem Sessel: Amokläufe, Terroranschläge, Massaker. Jetzt frage ich mich zum ersten Mal: Warum schaue ich mir das an? ... Man zückt das Smartphone, wenn es knallt. Als 
As Dachsel has clarified from the very start, looking away is not an alternative to checking and helping the ones in need. Looking away is alright when it is clear that one cannot do anything to help others but would only be a passive onlooker if one gazed at them. Here the viewer empathises with the victims and puts him- or herself in others' shoes. Once the viewer sees things also from another's perspective, he/ she can decide to protect the other's dignity by looking down. This kind of shame, the shame of discretion and decency (see Welz 20II), is the exact opposite to the exhibitionism of the terrorists who showcase atrocities.

While images of inhumanity, which combine the 'inhuman' cruelty of the perpetrators and the 'inhuman' humiliation of the victims, can evoke empathy with the ones who suffer, they also have a repelling effect. The viewer wants to take a distance rather than a closer look. Possibly this gut reaction changes over time, if one is regularly exposed to gruesome images and one's sensitivity is dulled - a point discussed by Susan

habe jeder Einzelne eine Reporterpflicht gegenüber der Welt. Was denkt ein Mensch, der Verletzte filmt, statt ihnen zu helfen? Und was fühle ich, wenn ich mir das anschaue? Vielleicht will er, unverhofft ins Chaos geraten, seiner unfreiwilligen Zeugenschaft einen Sinn verleihen. Er wechselt in jenem Moment, in dem er sein Smartphone zückt, von der Passivität des Beobachters zur Aktivität des Chronisten. Er, der Produzent, steht zwischen Leichentüchern und Blut. Ich, der Konsument, sitze im Wohnzimmer. Uns verbindet die Hoffnung, das Grauen sei mit Bildern zu zähmen. Als könne eine Gemeinschaft des Hinsehens weiteres Unheil abwenden. Unsere Vorstellung vom Bösen ist traditionell mit der Dunkelheit verknüpft. Mit den düsteren, unbeobachteten Ecken. Mit der Nacht. Wir glauben, das Grauenhafte sei zu vertreiben mit Wachsamkeit. Terroristen greifen uns aber nicht an, weil wir weggucken. Sie greifen uns an, weil wir hinsehen. Unser Reflex, die Tat zu filmen und zu verbreiten, ist Teil ihres Plans.
Sontag in Regarding the Pain of Others (2003). In themselves, images of horror are unlikely to prompt critical reflection and civil courage; yet they can do so if compared to reverse images that contain an implicit norm of what humanity should look like.

\section{Orienting images of humanity: the example of Michelangelo's Creation of Adam}

As an orienting image of humanity, the biblical imago Dei motif and its rendition in visual art, in particular by Renaissance artists, is central and has proved influential in European cultural history down to the present day. The image of the near-touching hands of God and Adam on the fresco painting Creazione di Adamo (Creation of Adam, I 5 I 2) by Michelangelo Buonarroti on

Terror ist ein Akt des Exhibitionismus.... Ich dachte, ich hätte Kontrolle über die Bilder. Dank Internet und digitaler Revolution. In Wahrheit aber haben die Bilder längst Kontrolle über mich. Ich träume von ihnen. Sie tauchen auf, wenn ich einen weißen Lastwagen sehe. Oder eine schwarze Fahne. Ich will nicht mehr.... Welchen Sinn soll es haben, dass ich diese Bilder in meinem Kopf lasse, von enthaupteten, gesprengten und überfahrenen Menschen? Es gibt Leute, die fordern, wir müssten hinsehen.... Doch bloße Augenzeugenschaft hilft niemandem. Und Entsetzen behindert manchmal das Verstehen.... Vielleicht ist es Zeit für die Wiederentdeckung eines alten Gefühls. Wir haben uns im Laufe des menschlichen Fortschritts, aus guten Gründen, von ihm entfernt: der Scham. Sie könnte uns in Zeiten der Terrorbilder, der schonungslosen Unmittelbarkeit, Sensibilität verleihen für die Frage, wann wir hinschauen dürfen. Und wann wir besser wegschauen. Wenn wir der Grausamkeit begegnen, dann ist es in Ordnung, mal den Blick zu senken. Wir sind schließlich beschämt. Beschämt über das, was wir Menschen uns antun. Wegschauen - auch das ist Mitgefühl.' 


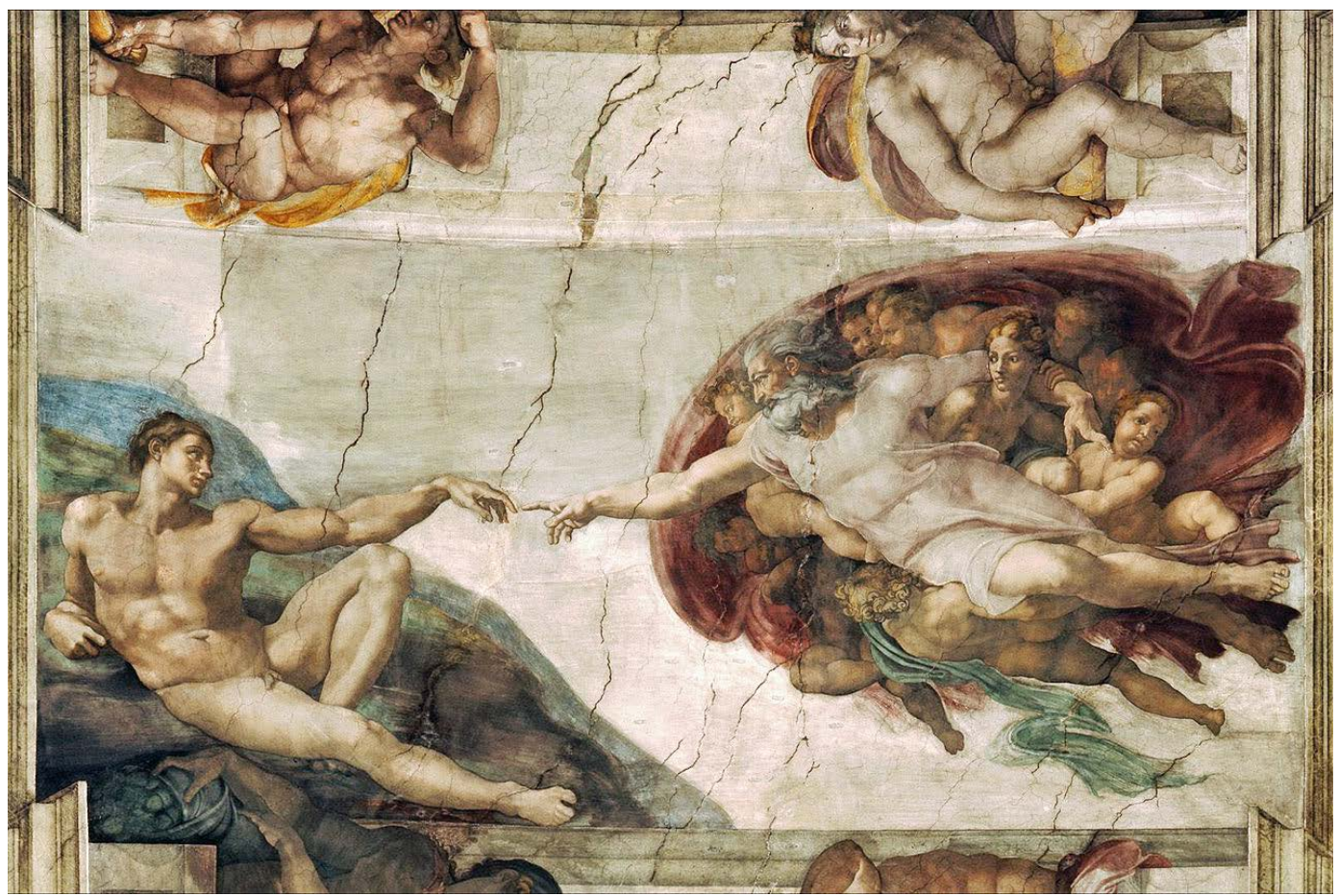

Michelangelo Buonarroti, Creazione di Adamo (1512), Sistine Chapel, Rome. Wikimedia Commons.

the Sistine Chapel's ceiling in Rome has become 'iconic of humanity'. 3

It illustrates at once the narrative of the creation of the human being in God's image (cf. Gen. r:26f.) and of God breathing the breath of life into Adam's nostrils (cf. Gen. 2:7). The anthropomorphic portrayal of God suggests, on the one hand, that Adam is created in God's likeness; yet on the other hand, God and man do not shake hands. Rather, the giver of life reaches out to his creature, which all the way through remains dependent on him. This is also suggested by another likely source of inspiration: the hymn Veni Creator Spiritus that asks the 'finger of the paternal right hand' (digitus paternae dexterae) to give the faithful speech. ${ }^{4}$ It is important to note that humanity is here portrayed

3 See 'The Creation of Adam' in Wikipedia (accessed on 16.4 .2018 ).

4 See 'The Creation of Adam' in Wikipedia, note I I (accessed on I6.4.20 I 8). vis-à-vis God, and this setting implies a criterion for human agency: the latter is defined as the highest standard that demands the greatest efforts - otherwise we cannot live up to the conversation with our divine counterpart, and our likeness to God disappears through our own fault.

Michelangelo laboured on the Sistine ceiling between 1508 and $15 \mathrm{I} 2$. In the centre of the ceiling are nine scenes from Genesis that can be associated with three great stages in human (pre-)history and destiny: ante legem (before the law of Moses), sub lege (under the law), sub gratia (under grace, cf. Rom. 5-8). The place of honour on the ceiling is reserved for the Creation of Adam, yet according to Renaissance theology, it is in the incarnation of God in Christ that human dignity, which was first manifested in the creation of Adam, is fully realised and restored (see O'Malley i 986: 92, 95f., i r6, I 24 ). Many Renaissance preachers and humanists paraphrased Giovanni Pico della Mirandola's 
Oration on the Dignity of Man (see ibid. I22, cf. Seymour I972: 83f., I 32-4I). Although the theologians at the papal court expended special effort in praising man's spiritual qualities, they by no means neglected the beauty and harmony they saw in the human body. In a sonnet by Michelangelo himself, the theme of humanity created in God's image and likeness recurs, and can almost be taken as a commentary on the painting (see O'Malley I986: I24, with reference to Michelangelo i 960: 6 of = no. Io6; 1963: 76 = no. I $_{4}$ ):

\section{né Dio sua grazia mi si mostra altrove}

God, in His grace, shows Himself nowhere more

più che 'n alcun leggiadro e mortal velo;

To me, than through some veil, mortal and lovely,

\section{e quell sol amo perch' in lui si specchia}

Which I will only love for being His mirror

The motif of the eternal God appearing in the shape of a mortal human being, and of human beings becoming theomorphous in salvation corresponds to Athanasius' phrase that 'God became man in order that man might become god' (Oratio de incarnatione verbi, ch. 54, $\left.{ }_{92} \mathrm{~B}\right)$. Here human deification is seen in relation to God's incarnation, the terminus ad quem of creation.

Becoming like God as goal description is the exact opposite of the bestiality of crimes against humanity where human beings act more bestially and brutishly than any animal could do. While Michelangelo's painting on the ceiling requires us to look up to heaven and to imagine our origin in God's life-giving creativity, atrocities committed by people who have 'sunk' so low make us cast down the eyes in shame over such a degradation of the human species. The movements upwards or downwards are diametrically opposed to each other, just as the humane or inhumane treatment of other human beings corresponds to antithetical options.

According to Alexander Nagel, the right arm and the legs of Adam in Michelangelo's painting resemble his thematically related investigations into the process by which an inanimate body comes to life:

the figure of Adam is an exquisite balance between agency and dependency. He is not simply a passive body lifted up from the ground by God .... Instead Adam is shown receiving and yet reaching, languid and yet instinct with an incipient autonomy. His upraised knee, like that of Lazarus, is a primary indicator of his stirring into life. (Nagel 2000: I 53f.)

In prolongation of the Genesis scenes recounted by Michelangelo - the cosmogony, the origins of humanity, original sin and the fatal burst of evil in the story (the Flood and the Drunkenness of Noab) - is The Last Judgment, a depiction of the second coming of Christ and the raising of the dead who either ascend to heaven or descend to hell. May we conclude that God, despite this open ending of history, does not abandon us, but will, in the end, ensure justice?

As Antonio Paolucci (2oro: I6) explains in regard to the Creation of Adam, 'God arrives in a glorious swirl magnified by his red cloak, engulfing the angels of his retinue as if they were protected by a wind-swollen sail, a personification of the Almighty's power'. Michelangelo seems to have trusted in the possibility that God finally overcomes evil, punishes the perpetrators and rewards those who suffered for the sake of the good, for instance the martyrs. This eschatological perspective reacts upon the view of the human condition here and now: our choices of good or evil matter infinitely. Michelangelo's paintings are reminders of the idea that our comportment on earth will also determine our 
afterlife. This way, visual images of (in)humanity contain a (more or less obvious or hidden) normativity. They call attention to the gravity of life-determining decisions whose effects we ourselves will have to bear. This might in itself work as an antidote to moral indifference.

In Michelangelo's creation fresco, God and Adam do not communicate at eye level, but God nonetheless makes eye contact with man. According to the Bible, God creates with the help of his creative word: 'Let us make mankind in our image, in our likeness' (Gen. $1: 26$ ). Traditionally, human likeness to God has also been located in the ability to speak, whereas violence entails the brutalisation of language. This brings us to the next point: images of (in)humanity in literature.

\section{Verbal and mental images of (in)humanity: Semprun}

While the refusal to look at visual images of inhumanity is comprehensible, the question is whether verbal images, that is, metaphors with pictorial content or linguistic expressions, which clothe thoughts in words and symbolise (in)humanity, can be bypassed. Or do such images prove necessary in order to identify the horror of atrocities, to rhetorically condemn inhumanity, and to cope with its consequences?

The Holocaust survivor Jorge Semprun had a good reason to postpone his testimony for about five decades. In his book L'écriture ou la vie (Literature or Life, I 994), he reflects upon the problem of evil and renders a conversation with an American lieutenant after the liberation of the concentration camp of Buchenwald in April I945:

'What's essential,' I tell Lieutenant Rosenfeld, is the experience of Evil. Of course, you can experience that anywhere.... You don't need concentration camps to know Evil. But here, this experience will turn out to have been crucial, and massive, invading everywhere, devouring everything. ... It's the experience of radical Evil.'

Startled, he looks at me sharply. Das radikal Böse! Obviously, he has caught the reference to Kant. ... I tell the American lieutenant that I should have begun this account with ... the stifling and fraternal stink of Sundays spent with Halbwachs and Maspero [who were dying].

'Evil is not what is inhuman, of course.... Or else it's what is inhuman in man.... The inhumanity of man, considered as vital possibility, as personal intention. ... As freedom. ... So it's ridiculous to oppose Evil, to distance oneself from it, through a simple reference to what is human, to mankind. ... Evil is one of the possible designs of the freedom essential to the humanity of man - the freedom from which spring both the humanity and inhumanity of man.' (Semprum I 997: 88)

In other words, inhumanity is understood as human nature turning against itself - as an option that presupposes the freedom of man who, as a human being, can comport in an inhuman manner. Semprun later makes it explicit that 'In Buchenwald, the SS, the Kapos, the informers, the sadistic torturers all belonged to the human race just as much as the best and purest among us, among the victims' (I 997: I64). In order to come to terms with the nonsense of torture and sadism, Semprun needs the paradoxical notion of humanity comprising the possibility of inhumanity in itself. The root of radical evil is, on this view, inherent in human freedom, which is double-edged.

Now, while the linguistic description of the problem of evil and its root in human beings can clarify the ambiguities, if not the abyss of the conditio humana, verbal images of (in)humanity have, in Semprun's case, not been able to help him to cope with the horror of atrocities. On 
the contrary. As the book title Literature or Life suggests, he was confronted with an alternative: either writing about evil (which made him relive its horrors and pulled him down) or living his life with the help of a cure of 'studied amnesia' and 'aphasia' (Semprun r 997: I 80, I96). Semprun's experience corresponds to the one of many other traumatised survivors (cf. Welz 2017 with reference to, e.g., Aharon Appelfeld, Otto Dov Kulka, Elie Wiesel, Sarah Kofman, and Dori Laub's research).

It follows that evil cannot be overcome just by telling about it - just as little as it can be overcome by means of photos ${ }^{5}$ or films documenting cruelty and its depressing results: suffering, death and destruction. Even though visual and verbal images of (in)humanity do not seem to have any therapeutic value, they may nonetheless provide Orientierung im Denken, that is, they can orient thinking. In his I 786 treatise Was heißt: Sich im Denken orientiren? Kant describes orienting oneself in and by thinking as a premise of reason that is withdrawn from its critique, enabling us to accept something as true. Remarkably, reason

5 However, photographic depiction can fulfil an important epistemic function. The so-called 'Sonderkommando photographs' (see Stone 200I), for instance, which were taken by inmates of the death camp Birkenau, are probably the only visual records of the Holocaust as it happened. They are not recollections or reconstructions after the fact; rather, their closeness to the actuality of genocide constitutes 'irrefutable evidence' (ibid. I 33). They have a 'visceral impact' on the shocked viewer (ibid. I 40). Yet they also emphasise a certain distance from the events. Stone (ibid. 142) quotes Susan Sontag (I 979: rogf.) in order to elucidate their double effect: 'photographs can and do distress. But the aestheticizing tendency of photography is such that the medium which conveys distress ends by neutralising it. ... Photography's realism creates a confusion about the real which is (in the long run) analgesic morally as well as (both in the long and in the short run) sensorially stimulating.' thereby 'feels' its own need, its being in need of orientation, and acknowledges its own limits (see Stegmaier 2008: 88f., 93).

Since we cannot think, speak or write about anything without having an 'idea' of what we are talking about, metaphors depend on mental images (or representations) in our mind: memories, dreams or intuitions. Do we, then, have to draw the same pessimistic conclusion regarding mental images as we did regarding visual and verbal images of (in)humanity? The case is complicated because mental images can only be communicated by being mediated. This implies that mental images can only appear together with other types of images. Semprun, for instance, tells us about the co-appearance of filmed (visual) and remembered (mental) images.

In the cinema in Locarno, he saw a newsreel on the discovery of the Nazi concentration camps by the Allied armies, where the camera's eye explored the interior of a hut: 'skeletal deportees at the end of their strength lay collapsed in bunks, staring fixedly at the intruders who were bringing - too late for many of them - their freedom'; moreover, the camera's eye watched the American army's bulldozers 'pushing hundreds of wasted corpses into common graves' (Semprun 1997: r 98). Semprun knew that these scenes had been filmed in different camps liberated by the Allied advance a few months before. And here is the account of the impact that these scenes have had on him:

There were also some images of Buchenwald, which I recognized. ... Or rather: I had experienced them. It was the difference between the seen and the experienced that was disturbing. Because it was the first time I'd seen such images. Until that winter's day - somewhat by chance, much more through a spontaneous strategy of self-defense - I'd managed to avoid filmed images of the Nazi camps. I had the ones in my memory, images that sometimes 
burst cruelly into my consciousness. Images I could also summon deliberately, even giving them a more or less structured form, organizing them into a course of anamnesis, a kind of narrative or intimate exorcism. That's exactly what they were: intimate images.... All of a sudden, though, in the quiet of that movie theater in Locarno, where the whispers and murmurs died away into a rigid silence of horror and compassion (and disgust, probably), these intimate images became foreign to me, objectified up on the screen. They also broke free to my personal procedures of memory and censorship. They ceased being my property and my torment, the deadly riches of my life. They were, finally, nothing more than the externalized, radical reality of Evil: its chilling yet searing reflection....

I saw myself returned to the truth of an indisputable experience. Everything had been true, so, it was all still true. Nothing had been a dream. In becoming, thanks to the film corps of the Allied armies, a spectator of my own life, a voyeur of my own experience, I felt as if I were escaping the wrenching uncertainties of memory. ... I had not imagined Buchenwald. ... Yet although the newsreel footage confirmed the truth of the actual experience (which was sometimes difficult for me to grasp and situate among my memories), at the same time these images underlined the exasperating difficulty of transmitting this truth, of making it, if not absolutely clear, at least communicable. (Semprun i 997: i99f.)

On the one hand, the newsreel corroborated and validated Semprun's personal experience; on the other hand, the film images in themselves were not sufficient to understand what had happened. For Semprun these images were 'silent' - not merely because they were filmed without sound recording, but 'above all because they said nothing precise about the reality they showed, because they delivered only confused scraps of meaning'; what was missing but 'really needed was commentary on the images, to decipher them, to situate them not only in a historical context but within a continuity of emotions' (Semprun I 997: 20I). While visual images have the capacity to externalise reality, so that we can distance ourselves from it, they do not in the same instance interpret the events they show. They need a beholder who can see and understand them as something from a certain perspective - and this can only be done on the basis of mental images that are brought into a certain order or structure with the help of thinking.

While the flashbacks of traumatised memory pop up involuntarily and thereby intensify the victim's feeling of helplessness and powerlessness, the activity of thinking can, at least to some extent, serve as a coping strategy. At its best, it can master the impressions and sensations linked to situations of overwhelming cruelty. Such situations' after-effects on those involved can be identified and worked through with the help of the faculty of imagination, which not only (re-)presents certain memories, but also transforms them by embedding these mental images in a broader context and by constantly updating the parameters framing it.

This discovery dovetails nicely with Arendt's defence of thinking - provided that one thinks also from another's point of view and remembers what one has done, thereby remaining in dialogue with oneself and integrating the past, the present and the future.

\section{Imagination in the service of the good}

Therefore, my preliminary conclusion is that visual, verbal and mental images in themselves are not enough to yield navigational tools and norms of orientation; yet the faculty that connects them and allows us to relate freely to these images, namely imagination as guided by critical thinking, can do so. 
Let me give a recent example from Danish history. In the night between I 4 and ${ }_{5}$ February 2015 , Dan Uzan was on voluntary guard duty in front of the synagogue at the Jewish Community in Copenhagen. Inside the community house a Bat Mitzvah celebration was taking place. A terrorist shot him. On a website established by his family, one can read the following lines:

\section{Daring to be kind}

Evil can never be vanquished through force, it can be overcome through human kindness [Danish: godhed; lit. 'goodness'] alone. It is the only hope for mankind and for our world entire. 6

On 28 September 20I6, there was a remarkable heading in the Danish news on the internet: 'Far til terroroffer: Dan skal hævnes med godhed' ('The father of the terror victim: Dan shall be avenged with goodness') (Christensen and Korsgaard 2016). Only the good is stronger than evil. Only the good can break the vicious circle of evil that engenders even more evil, if reciprocated and paid back like with like.

Again: visual, verbal or mental images of (in)humanity alone cannot do this job. What is needed is a human being who freely relates to these images and puts him- or herself in the service of goodness rather than evil. Yet this conclusion does not help us to face the problem of evil, let alone to 'solve' it. If evil is not located in images, from which we can distance ourselves, but rather in the beholder of these images or in the mind of the one who remembers them, evil is so close to us that we cannot run away from it. We take the problem with us. I agree with Kant and Semprun: human freedom is ambiguous.

While the problem of evil cannot be reduced to personal agents, the agency of human individuals contributes to it, not least in a Bildereignis,

6 See Dan Uzans Mindefond (accessed I6.4.2018). the event in which an image is seen by someone in a certain respect. Of course, images are not just tools that can be used for some agenda, but act upon us as well; we are affected even by the images that we ourselves have created. How, then, can we surpass our own acts of imagination and, in a way, see more than we can imagine - becoming surprised by yet unrealised possibilities? The life story and remembrance of Dan Uzan suggests that neither idolatry nor iconoclasm is the right way forward, but rather a human being's exemplary performance, which turns this person into a living image of the kindness he embodies. It is this image, which still lives on among us even after his death.

\section{Conclusion and prospect}

Let us recapitulate the line of reasoning so far. A comparative reading of Kant's and Arendt's interpretations of the problem of evil has shown various strengths and deficiencies in their respective theoretical frameworks. Kant's idea that evil is the matter of a misguided choice falls short in cases such as Eichmann's where evil results from indifference, while Arendt neglects the fact that, seen from the perspective of the victim, evil is never banal, and that leading historical figures like Hitler were not free from wicked intentions and strategies to implement them. Arendt's narrow focus on intellectual judgement and thoughtfulness as a barrier against thoughtlessly and carelessly committed evil was then broadened by discussing the ethical re-orientation through visual, verbal and mental images of (in)humanity.

The Hebrew word 'Adam' is not only a proper name, but also a generic noun that designates the 'human being'. In this line, Michelangelo's painting The Creation of Adam was presented as a reminder of a biblical vision of the origin and goal of humankind. The image contains an implicit norm of humanity, and, as such, it contrasts with images of atrocities denying 
human dignity. The question is how we can regain the status quo ante the Fall, if this is possible at all. If paradise is lost irretrievably, there is only one way: forwards, into the future. Yet can we improve ourselves, enhance our nature? On the basis of Semprun's reflections on the ambiguity of human freedom making itself unfree in evil-doing, I doubt the legitimacy of such an overly optimistic outlook. If we soberly accept human imperfection as the context of discovery where God's image can shine through, we might have to reconsider the real-life appearance of the imago Dei as a broken and incomplete image.

The image of an invisible God becomes 'visible' or accessible to human experience only if divine transcendence is mediated by a 'vision' with 'the mind's eye'. The spiritual needs embodiment in order to appear at all. This can happen in the following ways (cf. Welz 2or 6: ch. 6 and Conclusion): (r) The 'vision' of the image of God can arise through the figurative features of language, which include a reference to something that exceeds the realm of our experience. The imago Dei can be conceptualised as a communicative image insofar as we speak in response to God's word, which has called us into life. Humanity in God's image comes to the fore by virtue of verbal images: metaphors showing the similar in the dissimilar. (2) Colin McGinn (2004: 3) defines 'mindsight' as an imaginative seeing-as, where the dichotomy between perception and conception collapses in the hybrid of a vision that is both bodily and mental. Thus, visual images, too, play a role in understanding oneself and others as visible images of an invisible God. Divine-human co-presence in the imago Dei involves a looking-for-each-other, which, for instance, can be made intelligible on the analogy of an exchange of glances where our sight is summoned and subverted, so that the one who looks also feels looked at. (3) Last but not least, the imago Dei becomes visible with the help of mental images of an invisible God. 'Inner' images differ from ordinary perception in arising even without stimuli 'from outside'.
Memory, language, and the power of imagination enable us to envision, to recall, and to articulate the invisible.

If one takes the preposition in the Hebrew

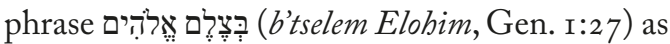
bet essentiae, then human beings are created as God's images; if one takes it as bet normae, then human beings are created in or according to the image of God. As living, speaking, embodied images that are created in or according to the image of God, we realise that we can either reveal or conceal God's presence, and thus display or overshadow our likeness to God. Hence, the image of the divine in the human is still awaiting its future fulfilment. As a normative limit-concept, the imago Dei cannot be grasped, but only approximated. Its liminality comes to the fore in metaphors instilling a sense of possibility in language. Metaphors are like 'organs' for the new and foreign, for the not-yetseen that can still be formed and re-formed (cf. Bjerg 1999: 187, 189, I9I). In this sense, the imago Dei is an intuited image of what we are to become.

The move from the imago Dei to the imitatio Dei, from an image 'seen' only in theory to the ethical praxis of imitation, can only be completed in linguistic communion with the One in whose image we are created and the ones who are our fellow creatures. This is a move beyond images, which ultimately leads us from vision to audition, from seeing to listening.

Claudia Welz is Professor of Systematic Theology with special responsibilities in Ethics and Philosophy of Religion at the University of Copenhagen and Founding Director of CJMC: Center for the Study of Jewish Thought in Modern Culture. She is the author of the

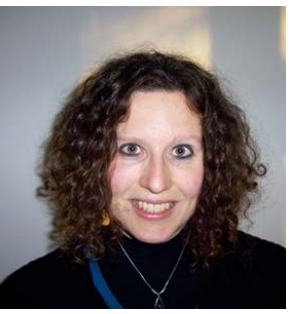
monographs Love's Transcendence and the Problem of Theodicy (Mohr Siebeck, 2008), Vertrauen und Versuchung (Mohr Siebeck, 2010), and Humanity in God's Image: An Interdisciplinary Exploration (Oxford University Press, 2016). 


\section{References}

Arendt, Hannah, I 978. The Life of the Mind (San Diego, New York and London, Harcourt)

-2003. 'Some questions of moral philosophy', Responsibility and Judgment, ed. Jerome Kohn (New York, Schocken Books), pp. 49-I 46 2006. Eichmann in Jerusalem: A Report on the Banality of Evil (New York, Penguin)

-2007. The Jewish Writings, eds Jerome Kohn and Ron H. Feldman (New York, Schocken Books)

Augstein, Franziska, 20 Io. 'Taten und Täter: Ein Nachwort', Hannah Arendt, Über das Böse. Eine Vorlesung zu Fragen der Ethik, ed. Jerome Kohn, trans. Ursula Ludz (München and Zürich, Piper), pp. I 77-95

Benhabib, Seyla, r 990. 'Hannah Arendt and the redemptive power of narrative', Social Research, 57(I), pp. I67-96

Benjamin, Andrew, 2016. Virtue in Being: Towards an Ethics of the Unconditioned (Albany, State University of New York Press)

Bernstein, Richard J., 2002. 'Reflections on radical evil: Arendt and Kant', Soundings: An Interdisciplinary Journal, 85(I-2), pp. I 7-30

Bjerg, Svend, I 999. Synets Teologi (Frederiksberg, Anis)

Christensen, Joachim Hans Næshave, and Peter Led Korsgaard, 2016. 'Far til terroroffer: Dan skal hævnes med godhed', DR [Danish Broadcasting Corporation], 27.9.2016, <http://www.dr.dk/nyheder/regionale/ hovedstadsomraadet/far-til-terrorofferdan-skal-haevnes-med-godhed $>$ (accessed 28.9.2016)

'The Creation of Adam', Wikipedia, < https:// en.wikipedia.org/wiki/The_Creation_of_ Adam> (accessed I6.4.20I 8)

Dachsel, Felix, 20I 6. 'Ansage: Ich will das nicht mehr sehen', DIE ZEIT, 3 I (July 2 I), p. 56

Dan Uzans Mindefond. The Memorial Foundation, <http://danuzan.com/index/> (accessed I6.4.2018)

Eaglestone, Robert, 201 7. The Broken Voice: Reading Post-Holocaust Literature (Oxford University Press)

Geddes, Jennifer, 2009. 'Banal evil and useless knowledge: Hannah Arendt and Charlotte Delbo on evil after the Holocaust', The Double Binds of Ethics after the Holocaust, eds Jennifer L. Geddes, John K. Roth and Jules Simon (New York, Palgrave Macmillan), pp. I I 9-32 -20I3. 'Evil', The Oxford Handbook of Theology and Modern European Thought, eds Nicholas Adams, George Pattison, and Graham Ward (Oxford University Press), pp. 2 I 3-3 I

Jaspers, Karl, I 992. 'Letter no. 46', Hannah Arendt Karl Jaspers: Correspondence 1926-1969, eds Lotte Kohler and Hans Saner, trans. Robert and Rita Kimber (New York, San Diego and London, Harcourt Brace Jovanovich), pp. 6o-3

Kant, Immanuel, I 990/ I 998. Die Religion innerbalb der Grenzen der bloßen Vernunft, ed. Karl Vorländer (Hamburg, Felix Meiner, I 990). Religion within the Boundaries of Mere Reason, trans. and ed. Allen Wood and George Di Giovanni (Cambridge University Press, I998)

McGinn, Colin, 2004. Mindsight: Image, Dream, Meaning (Cambridge, MA, Harvard University Press)

Michelangelo, I 960/ 1963. Rime, ed. Enzo Noé Girardi (Bari, Laterza, I960). English translation by Creighton Gilbert, Complete Poems and Selected Letters of Michelangelo (New York, Random House, I 963)

Nagel, Alexander, 2000. Michelangelo and the Reform of Art (Cambridge University Press)

Neiman, Susan, 2002. Evil in Modern Thought: An Alternative History of Philosophy (Princeton University Press)

Nietzsche, Friedrich, 2008. Beyond Good and Evil, trans. and ed. Marion Faber (Oxford University Press)

O'Malley, John, I 986. 'The theology behind Michelangelo's ceiling', The Sistine Chapel: The Art, the History, and the Restoration, ed. Massimo Giacometti (New York, Harmony Books), pp. 92-I 48

Pack, Justin, 20 I 7. 'Arendt's genealogy of thinking', Continental Philosophy Review, 5 o, pp. I 5 I -64

Paolucci, Antonio, 20 Io. The Sistine Chapel, trans. Catherine Burnett, Edizioni Musei Vaticani (Livorno, Sillabe)

Schanz, Hans-Jørgen, 2007. Handling og ondskab. En bog om Hannah Arendt (Aarhus Universitetsforlag)

Semprun, Jorge, I 997. Literature or Life, trans. Linda Coverdale (New York, Penguin Books)

Seymour, Jr., Charles, I 972 . Michelangelo: The Sistine Chapel Ceiling (New York, W.W. Norton)

Sontag, Susan, I 979. On Photography (London, Penguin)

2003. Regarding the Pain of Others (London, Penguin) 
Stegmaier, Werner, 2008. Philosophie der Orientierung (Berlin and New York, Walter de Gruyter)

Stone, Dan, 200r. 'The Sonderkommando photographs', Jerwish Social Studies New Series, 7(3), pp. I $3 \mathrm{I}-48$

Vetlesen, Arne Johan, 200 r. 'Hannah Arendt on conscience and evil', Philosophy and Social Criticism, 27(I), pp. I-33

Welz, Claudia, 2or r. 'Shame and the hiding self', Passions in Context: International Journal for the History and Theory of Emotions, 2: Atrocities -Emotion - Self(August 201 I), pp. 67-92

2016. Humanity in God's Image: An Interdisciplinary Exploration (Oxford University Press)

20I7. 'A voice crying out from the wound with or without words: on trauma, speech, and silence', Dialog: A Journal of Theology, 56 (4), pp. 4I 2-27 <http://rdcu.be/AqxA>

20 18. 'Self-knowledge and self-deception: existential hermeneutics and psychoanalysis', Hermeneutics and Negativism: Existential Ambiguities of Self-Understanding, eds Claudia Welz and René Rosfort (Tübingen, Mohr Siebeck), pp. 237-55

Willeke, Stefan, 20 16. "Wir lachen ständig”: Der inhaftierte Kriegsverbrecher Radovan Karadžić äußert sich erstmals über sein Leben nach der Verurteilung', DIE ZEIT, 39 (I 5 September), p. I 2

Wojak, Irmtrud, 200 I. Eichmanns Memoiren: Ein kritischer Essay (Frankfurt, Campus-Verlag)

Zygelboym, Shmuel, I 995. 'Shmuel Zygelboym: where is the world's conscience?', The Jew in the Modern World: A Documentary History. Second Edition, eds Paul Mendes-Flohr and Jehuda Reinharz (New York, Oxford University Press), p. 683 